\title{
The Levels of Classroom and Pre-school Teachers' Metacognitive Awareness
}

\author{
İlhami Bulut \\ Ziya Gökalp Faculty of Education, Dicle University, Turkey
}

Copyright $\mathrm{C} 2018$ by authors, all rights reserved. Authors agree that this article remains permanently open access under the terms of the Creative Commons Attribution License 4.0 International License

\begin{abstract}
The goal of this study is to specify the metacognitive awareness levels of the classroom and pre-school teachers. Metacognitive awareness of teachers has been an important research subject in educational literature. However, current research on this topic is limited Therefore, there is more need for this kind of research and this reality makes the current research more important. Data were collected using "Metacognitive Awareness Inventory (MAI)" which was developed by Schraw and Dennison [1] translated into Turkish by Akın, Arabacı \& Cetin [2]. The participants were 396 teachers in the primary school and pre-schools of Diyarbakir in the 2018-2019 academic year. Data were analyzed in terms of branch, gender and seniority variables. In analysing data, t-test, one-way analysis of variance (ANOVA) and Scheffe tests were used. Results showed the levels of the classroom and pre-school teachers' awareness was high. It was also found that the branch and gender variables were effective on teachers' metacognitive awareness levels, while the seniority variable was not. It is necessary to develop learning strategies to improve teachers' metacognitive awareness.
\end{abstract}

Keywords Metacognitive Awareness, Metacognitive Skills, Classroom and Pre-school Teachers

\section{Introduction}

Metacognition is a term that has been frequently accentuated in recent years. The main reason for this emphasis on metacognition is to ensure competences like "lifelong learning" and "self-learning", depending on gaining wide importance of cognitive psychology in education. The reason of the interest shown in metacognition is based on the assumption that this competence is essential in gaining these competencies [3].

Garrison, Anderson \& Archer [4] state that social, cognitive and educational assets are essential in the realization of an effective educational experience.
Similarly, Bandura [5] states that cognitive, reflective and self-regulating skills play an important role in social cognitive theory. The processes have importance especially when it is used by the individual to increase the effectiveness of the learning process while structuring information in the mind [6].

Kilis \& Yildirim [7] state that metacognition has been discussed around the concept of self-regulation. Lajoie [8] states that the concept of metacognition is intertwined with the concepts of self-regulation and self-regulated learning, and is often used interchangeably in the literature. According to Baker \& Brown [9], metacognition is a self-regulating mechanism. In the light of these explanations, it can be argued that self-regulated learning involves the concept of metacognition [10-11-12]. Self-regulated learning includes cognitive, metacognitive, behavioral, motivational and emotional aspects of learning [13]. In this research, the concepts of metacognition, metacognitive control/metacognitive skills and cognitive awareness are discussed.

\subsection{Metacognition}

The term of metacognition was first used in 1976 by Flavell [14]. The term metacognition is also referred to in the literature as "executive cognition", "metacognition" and "cognition of cognition" [15]. Metacognition is defined as an individual's knowledge about cognitive processes [16-17-18-19-20]. Metacognition is a cognitive structure that allows the individual to follow and understand his/her cognitive processes [20-21] to control [17-22-23-24] and enable individuals to think in a high level [24]. Thus, metacognition allows the individual to be aware of the processes of thinking and learning and to control these processes [23-25].

In the literature, it is seen that metacognitive studies are examined under the headings of metacognitive knowledge and cognitive control [26]. Cognition includes the skills required to encode, store, and retrieve information [20]. Metacognitive knowledge consists of deep insight, knowledge and awareness components in the cognitive 
processes of the individual. In other words, it refers to the awareness of the mental processes of the individual and the knowledge and beliefs about the sources of cognition [22]. According to this, while learning a subject, an individual should question his/her aim and the product expected to be reached, what he/she knows about the subject and the method that should be followed to learn the subject efficiently [19]. According to [9], metacognitive knowledge is related to the individual's knowledge of his or her cognitive resources and capacity in a learning situation. Medina, Castleberry \& Persky [27] describe metacognitive knowledge as the information that the individual considers when he or she thinks of an idea, and state that this knowledge consists of simple facts and concepts.

Metacognitive knowledge consists of declarative, procedural and conditional structures [28]. Declarative information is defined as a network of information about events and views that an individual uses to describe the external world [29]. Kyllonen \& Woltz [30] describe procedural information as the knowledge of doing something and to know the question of "how" about something. Situational information is; to know which information an individual can use in a situation that he/she encounters, and this knowledge requires both having explanatory and procedural information [31].

Metacognition is considered to be an educable and developable ability, and it is thought to starts to develop at a young age, and continues to develop in parallel with the growth and development of the individual. The common view is that it is possible to use this ability, which consists of at younger age can be controlled and used in learning process at later age [3]. It is also stated that adults have more information about their cognition and they can describe this information better than children [32].

\subsection{Metacognitive Control/Metacognitive Skills}

Metacognitive control, in a sense, is the skill to utilize metacognitive knowledge [33]. According to Medina, Castleberry \& Persky [27], metacognitive control is the ability to identify and regulate activities. Metacognitive control, in other words, metacognitive abilities enables the individual to use and regulate information [34] and to control cognitive processes [35-36-34]. In this way, the individual organizes, supervises and manages the learning process [37]. Through metacognitive skills, the individual effectively manages his / her emotions, behaviors and thoughts in the learning process [38].

According to Pintrich, Wolters \& Baxter [10], metacognitive skills include planning, strategy selection, resource allocation, and voluntary control abilities. When the metacognitive skills are examined in the literature, it is generally observed that the prediction, planning, monitoring and evaluation abilities have come to the foreground [26]. The first of the metacognitive skills is estimating. This ability allows the learner to use effectively learning purposes, characteristics of learning and timing. In this process, the learner estimates the degree of difficulty of activity in the classroom, and uses metacognitive processes based on estimation to achieve effective results. Therefore, the learner makes difficult tasks slowly and easy tasks faster in the class [39]. The second is planning, which involves selecting appropriate strategies and allocating cognitive resources for effective performance [2]. Planning ability allows the learner to think about why, how and when to reach their goals [39]. The third is monitoring. Monitoring involves analyzing performance, predicting about following performance, assessing the efficiency of learning strategies, and identifying performance errors [40]. The monitoring ability allows the learner to review his/her plans, to identify problems and to control and use the cognitive processes in the learning process. The last metacognitive ability is evaluation, which includes learning outcomes and its efficiency [41].

In addition to these, Schraw \& Dennison [1] state that debugging and managing information are among in metacognitive skills. The former involves identifying and correcting errors in the performance of an individual. The latter includes skills such as organizing, elaboration, and summarizing information to use it more effectively for learning purposes.

Medina, Castleberry \& Persky [27] indicate that metacognitive skills have a significant impact on critical thinking and problem solving. Further, the deficiency of metacognitive abilities has been shown to be one of the major reasons why students fail in some lessons [16].

\subsection{Metacognitive Awareness}

Metacognitive awareness refers to the knowledge that individuals have about their thinking processes and strategies and their abilities to monitor and regulate these processes [15]. Metacognitive awareness requires the individual to think on his/her own learning with the aim of analyzing and monitoring these learning processes.

According to Bonds, Bonds \& Peach [42] metacognitive awareness refers to control, evaluation and monitoring of an individual's thoughts. Metacognitive awareness is an awareness related to individuals' problem solving strategies, individual learning, knowing the stage of a problem-solving process. Metacognitive awareness includes the knowledge that if individuals should do and know what to do in special situations [43].

The individual, who is aware of his/her own learning, the subject and the target that he/she learns, taking responsibility of his/her own learning, can be better motivated and more successful. In the learning-teaching process, if it is demanded from the students to construct information meaningly with an active, responsible and in-depth perception, it is necessary to realize "thinking process and its knowledge". Metacognitive awareness takes part in the focus of recognizing the skills to think and 
learning how to learn [44]. Considering that learning continues throughout life, it can be said that individuals who are aware of how they learn is of great importance in terms of learning to learn [45]. In a sense, metacognition is an important skill for lifelong learning [27] and underlie lifelong learning [46].

Research [47-25-48-49] shows that metacognitive skills and awareness enhance learning. For example, according to Hattie [50], metacognition is a strong determinant of learning outcomes. Similarly, a study by Paris and Jacobs [51] indicates that the development of metacognition resulted in progress in learning. Research results show that metacognition has a positive effect on learning outcomes. For this reason, Garofalo \& Lester [52] state that metacognitive training in schools should be implemented through a systematic and organized program and teachers have an important role in this training process.

Metacognition is important for the professional development of teachers. Considering the effective role of teachers in training metacognition, it is seen that the research about teachers in this subject is quite limited [16]. However, it is necessary to specify the grade of metacognitive awareness of teachers. Considering the importance of early education, it is thought that determining the metacognitive awareness of classroom and pre-school teachers will contribute significantly to the field, teachers and program development experts.

\section{Method}

\subsection{Research Goal}

The main goal of this research is to identify the level of classroom and pre-school teachers' metacognitive awareness. Sub aims determined in this regard are; (I) What are the levels of classroom and pre-school teachers' metacognitive awareness in terms of the total dimension and sub-dimension inventory? (II) Is there a significant difference between the levels of classroom and pre-school teachers' metacognitive awareness in terms of the total dimension and sub-dimension inventory by branch, gender and seniority?

\subsection{Research Design}

The study is a descriptive design. Consequently, the survey design has been used in the research. The survey design defines a current state which was in the bygone or just now in present as it is [53].

\subsection{Sample and Data Collection}

The population of this research consists of classroom and pre-school teachers employed at public primary schools and kindergartens in Diyarbakir central district in the fall semester of the 2018-2019 academic year.
Population is composed of 3507 teachers including 2804 classrooms and 703 pre-schools; however as it is not possible to implement the scale to the all population [55], simple random sampling was applied in this research.

In simple random sampling, an unbiased selection is done by relying on the equivalent possibility of selection for each participant in the population [54]. Roscoe, points out that having a sample bigger than 30 and smaller than 500 is enough for much research in respect to sample size [55]. Similarly, Balci [54] points out that the rate of the population to the sample being $3 \%-5 \%$ is sufficient to indicate the size of the whole population. Considering these, the current study included a the research sample composed of 396 teachers (188 male, 208 female) selected randomly. Of this number, were 297 classroom teachers from 18 primary schools and 99 were preschool teachers from 13 kindergartens in Diyarbakir. In this research, the rate of the sample to the population is $8.9 \%$, which indicates that the sample represents the population. In terms of participant teachers' professional seniority; 75 teachers are 1-5 years, 122 are 6-10 years, 104 are 11-15 years, 51 are 16-20 years and 44 are 21 and high.

This study used a Turkish translation [2] of Metacognitive Awareness Inventory (MAI) which was originally developed in English by Schraw \& Dennison [1] and it was adapted by Akin et al. [2]. MAI has 52 items. Akin et al. [2] found the concurrent validity of the MAI as .95 and stated item-test correlations of sub-dimensions varied between .35 and .65 . as a result of analysis. Also, in this research internal consistency and test-retest reliability coefficients of the MAI was found as .95. In this study, reliability coefficients related to the MAI and it's sub-dimensions are supplied in Table 1.

Table 1. Reliability Coefficients Calculated with MAI by the Cronbach's Alpha

\begin{tabular}{ll}
\hline Sub-dimension & $\begin{array}{l}\text { Internal Consistency } \\
\text { (Cronbach's Alpha) }\end{array}$ \\
\hline Declarative knowledge & .77 \\
\hline Procedural knowledge & .59 \\
\hline Conditional knowledge & .68 \\
\hline Planning & .76 \\
\hline Monitoring & .76 \\
\hline Evaluation & .73 \\
\hline Debugging & .73 \\
\hline Information management & .76 \\
\hline Total inventory & .95 \\
\hline
\end{tabular}

In the Table 1, Cronbach Alpha reliability coefficients are measured to be .95 for the all inventory. The inventory includes eight sub-dimensions and it changes between .59 and .77 for sub-deminsions. It can be point out that few number of items in the procedural knowledge sub-dimension can be the major causes. Usually inventories with Cronbach Alpha reliability coefficients of .70 and higher are accepted as reliable [56]. However it 
is stated that Cronbach Alpha reliable coefficients over .50 can be a measure for inventories that have less items [45]. According to this knowledge, it can be propounded that the MAI and its sub-dimensions are acceptably reliable.

Data collection tool consist of two sections. The first section contains personal information and the second section contains MAI. In the personal information section, there are items about teachers' branch, gender and seniority. The second section includes MAI, which consists of 8 sub-dimensions by Schraw \& Dennison [1]. These sub-dimensions are; (i) declarative knowledge, (ii) procedural knowledge, (iii) conditional knowledge, (iv) planning, (v) monitoring, (vi) evaluation, (vii) debugging and information management [1].

\subsection{Analysis of Data}

Data collection tool was distributed to the participants by the researcher in person.

The MAI is a five-point Likert-type scale. The MAI comprises of these five choices (strongly agree, agree, partly agree, disagree and strongly disagree) scale span was determined as $5-1=4,4 / 5=0.80$. The choice ranges of the scale are as follows: $1.00-1.80$ : very low; $1.81-2.60$ : low; 2.61-3.40: medium; 3.41-4.20: high; 4.21-5.00: very high.

In metacognitive awareness of every expression in all 8 sub-dimensions of the inventory, standard deviation and arithmetic mean was utilized. In order to determine the statistical methods to be used in the analysis of the data collected from the study, it is chosen to look at the distribution charts of the data. It is better to look at the graphs that show the normal distribution in the studies which are $n>200$ [57]. In this study, since the data distribution is normal, parametric tests should be used. In order to analyse the data collected if there were any significant differences between means in respect to branch and gender, an independent samples t-test was used. In case of there is a significant difference between means in respect to seniority, one way variance analysis (ANOVA) was applied. In a condition of significant differences, Scheffe test was used to compare between which groups the difference was 5 points: $1=$ Strongly disagree I can -$5=$ Strongly agree $\mathrm{I}$ can. The significance level was taken as .05 . All the items in the inventory are positive.

\section{Results}

Research results were presented in order of the sub goals of the research.

\subsection{The Levels of Classroom and Pre-school Teachers' Metacognitive Awareness}

The first sub-objective of the research is investigating the levels of classroom and pre-school teachers' metacognitive awareness on the MAI.

When the mean scores (max: 5, min: 1) in Table 2 are considered, it can be clearly seen that the levels of teachers' metacognitive awareness about the declarative knowledge $(\overline{\mathrm{X}}=3.97)$, procedural knowledge $(\overline{\mathrm{X}}=3.86)$, conditional knowledge $(\overline{\mathrm{X}}=4.06)$, planning $(\overline{\mathrm{X}}=3.96)$, monitoring $(\overline{\mathrm{X}}=3.94)$, evaluation $(\overline{\mathrm{X}}=3.86)$, debugging $(\overline{\mathrm{X}}=3.90)$, information management $(\overline{\mathrm{X}}=3.98)$ and total inventory $(\overline{\mathrm{X}}=3.95)$ are high.

Table 2. The Levels of Classroom and Pre-School Teachers' Metacognitive Awareness

\begin{tabular}{lll}
\hline Sub-Dimensions & $\overline{\mathrm{X}}$ & $\mathrm{SD}$ \\
\hline Declarative knowledge & 3.97 & .529 \\
\hline Procedural knowledge & 3.86 & .582 \\
\hline Conditional knowledge & 4.06 & .525 \\
\hline Planning & 3.96 & .568 \\
\hline Monitoring & 3.94 & .521 \\
\hline Evaluation & 3.86 & .588 \\
\hline Debugging & 3.90 & .601 \\
\hline Information management & 3.98 & .493 \\
\hline Total inventory & 3.95 & .471 \\
\hline
\end{tabular}

\subsection{The Levels of Teachers' Metacognitive Awareness in terms of Branch, Gender and Seniority}

The second sub objective of the research is investigating the levels of teachers' metacognitive awareness according to the total dimension and sub-dimension inventory by branch, gender and seniority.

\subsubsection{Results in Terms of Branch}

Table 3 presents results the levels of classroom and pre-school teachers' metacognitive awareness in terms of branch variable.

Table 3 indicates that there are significant differences between the classroom and pre-school teachers' opinions on the declarative $\left[\mathrm{t}_{(394)}=4.505,{ }^{*} \mathrm{p}<.05\right]$, procedural $\left[\mathrm{t}_{(394)}=3.045, \quad * \mathrm{p}<.05\right]$ and conditional knowledge $\left[\mathrm{t}_{(394)}=3.265, * \mathrm{p}<.05\right]$, planning $\left[\mathrm{t}_{(394)}=4.032, * \mathrm{p}<.05\right]$, monitoring $\left[\mathrm{t}_{(394)}=3.032, * \mathrm{p}<.05\right]$, evaluation $\left[\mathrm{t}_{(394)}=4.597\right.$, $\left.{ }^{*} \mathrm{p}<.05\right]$, debugging $\left[\mathrm{t}_{(394)}=4.170, * \mathrm{p}<.05\right]$, information management $\left[\mathrm{t}_{(394)}=2.966, * \mathrm{p}<.05\right]$ and total inventory $\left[\mathrm{t}_{(394)}=4.322,{ }^{*} \mathrm{p}<.05\right]$ in favor of pre-school teachers. According to arithmetic means, pre-school teachers have a higher level of awareness about the MAI according classroom teachers although both classroom and pre-school teachers have high levels of metacognitive awareness.

\subsubsection{Results In Terms of Gender}

Table 4 presents results the levels of classroom and pre-school teachers' metacognitive awareness according to gender variable. 
Table 3. Results about Teachers' Metacognitive Awareness According to Branch Variable

\begin{tabular}{|c|c|c|c|c|c|c|}
\hline Sub-Dimensions & Branch & $\mathrm{n}$ & $\overline{\mathrm{X}}$ & SD & $\mathrm{t}$ & $\mathrm{p}$ \\
\hline \multirow{2}{*}{ Declarative knowledge } & classroom teacher & 297 & 3.90 & .531 & \multirow{2}{*}{4.505} & \multirow{2}{*}{$.000^{*}$} \\
\hline & pre-school teacher & 99 & 4.17 & .471 & & \\
\hline \multirow{2}{*}{ Procedural knowledge } & classroom teacher & 297 & 3.81 & .595 & \multirow{2}{*}{3.045} & \multirow{2}{*}{$.002 *$} \\
\hline & pre-school teacher & 99 & 4.02 & .516 & & \\
\hline \multirow{2}{*}{ Conditional knowledge } & classroom teacher & 297 & 4.01 & .539 & \multirow{2}{*}{3.265} & \multirow{2}{*}{$.001 *$} \\
\hline & pre-school teacher & 99 & 4.21 & .455 & & \\
\hline \multirow{2}{*}{ Planning } & classroom teacher & 297 & 3.89 & .573 & \multirow{2}{*}{4.032} & \multirow{2}{*}{$.000^{*}$} \\
\hline & pre-school teacher & 99 & 4.15 & .506 & & \\
\hline \multirow{2}{*}{ Monitoring } & classroom teacher & 297 & 3.90 & .523 & \multirow{2}{*}{3.032} & \multirow{2}{*}{$.003^{*}$} \\
\hline & pre-school teacher & 99 & 4.08 & .491 & & \\
\hline \multirow{2}{*}{ Evaluation } & classroom teacher & 297 & 3.78 & .598 & \multirow{2}{*}{4.597} & \multirow{2}{*}{$.000^{*}$} \\
\hline & pre-school teacher & 99 & 4.09 & .492 & & \\
\hline \multirow{2}{*}{ Debugging } & classroom teacher & 297 & 3.83 & .596 & \multirow{2}{*}{4.170} & \multirow{2}{*}{$.000^{*}$} \\
\hline & pre-school teacher & 99 & 4.11 & .565 & & \\
\hline \multirow{2}{*}{ Information management } & classroom teacher & 297 & 3.94 & .477 & \multirow{2}{*}{2.966} & \multirow{2}{*}{$.003 *$} \\
\hline & pre-school teacher & 99 & 4.11 & .519 & & \\
\hline \multirow{2}{*}{ Total inventory } & classroom teacher & 297 & 3.89 & .465 & \multirow{2}{*}{4.322} & \multirow{2}{*}{$.000^{*}$} \\
\hline & pre-school teacher & 99 & 4.12 & .445 & & \\
\hline
\end{tabular}

$* \mathrm{p}<.05$

Table 4. Results about Teachers' Metacognitive Awareness according to Gender Variable

\begin{tabular}{|c|c|c|c|c|c|c|}
\hline Sub-Dimensions & Gender & $\mathrm{n}$ & $\overline{\mathrm{X}}$ & $\mathrm{SD}$ & $\mathrm{t}$ & $\mathrm{p}$ \\
\hline \multirow{2}{*}{ Declarative knowledge } & Male & 188 & 3.86 & .538 & \multirow{2}{*}{4.054} & \multirow{2}{*}{$.000 *$} \\
\hline & Female & 208 & 4.07 & .501 & & \\
\hline \multirow{2}{*}{ Procedural knowledge } & Male & 188 & 3.81 & .558 & \multirow{2}{*}{1.842} & \multirow{2}{*}{.066} \\
\hline & Female & 208 & 3.91 & .600 & & \\
\hline \multirow{2}{*}{ Conditional knowledge } & Male & 188 & 3.94 & .537 & \multirow{2}{*}{4.343} & \multirow{2}{*}{$.000 *$} \\
\hline & Female & 208 & 4.17 & .492 & & \\
\hline \multirow{2}{*}{ Planning } & Male & 188 & 3.88 & .561 & \multirow{2}{*}{2.806} & \multirow{2}{*}{$.005 *$} \\
\hline & Female & 208 & 4.03 & .565 & & \\
\hline \multirow{2}{*}{ Monitoring } & Male & 188 & 3.89 & .493 & \multirow{2}{*}{1.989} & \multirow{2}{*}{$.047 *$} \\
\hline & Female & 208 & 3.99 & .541 & & \\
\hline \multirow{2}{*}{ Evaluation } & Male & 188 & 3.74 & .586 & \multirow{2}{*}{3.835} & \multirow{2}{*}{$.000^{*}$} \\
\hline & Female & 208 & 3.96 & .570 & & \\
\hline \multirow{2}{*}{ Debugging } & Male & 188 & 3.77 & .579 & \multirow{2}{*}{4.194} & \multirow{2}{*}{$.000 *$} \\
\hline & Female & 208 & 4.02 & .596 & & \\
\hline \multirow{2}{*}{ Information management } & Male & 188 & 3.91 & .485 & \multirow{2}{*}{2.611} & \multirow{2}{*}{$.009^{*}$} \\
\hline & Female & 208 & 4.04 & .493 & & \\
\hline \multirow{2}{*}{ Total inventory } & Male & 188 & 3.86 & .461 & \multirow{2}{*}{3.683} & \multirow{2}{*}{$.000 *$} \\
\hline & Female & 208 & 4.03 & .465 & & \\
\hline
\end{tabular}

*p $<.05$

Table 4 shows that there are significant differences between male and female teachers' opinions about the declarative knowledge $\left[\mathrm{t}_{(394)}=4.054, * \mathrm{p}<.05\right]$, conditional knowledge $\left[\mathrm{t}_{(394)}=4.343, * \mathrm{p}<.05\right]$, planning $\left[\mathrm{t}_{(394)}=2.806\right.$, $* \mathrm{p}<.05]$, monitoring $\left[\mathrm{t}_{(394)}=1.989,{ }^{*} \mathrm{p}<.05\right]$, evaluation $\left[\mathrm{t}_{(394)}=3.835, * \mathrm{p}<.05\right]$, debugging $\left[\mathrm{t}_{(394)}=4.194, * \mathrm{p}<.05\right]$, information management $\left[\mathrm{t}_{(394)}=2.611, * \mathrm{p}<.05\right]$ and total inventory $\left[\mathrm{t}_{(394)}=3.683,{ }^{*} \mathrm{p}<.05\right]$ in favor of female teachers. Accordingly, it is clearly seen that the level of awareness of female teachers on the declarative and conditional knowledge, planning, monitoring, evaluation, debugging, information management and total inventory is higher than that of the male teachers. On the other hand, the teachers' opinions on procedural knowledge $\left[\mathrm{t}_{(394)}=3.045, \mathrm{p}>\right.$.05] did not change according to gender variable. According to arithmetic means, female teachers have a higher level of metacognitive awareness about the total and sub-dimensions of inventory according male teachers.

\subsubsection{Results In Terms of Seniority}

Table 5 presents results the levels of classroom and pre-school teachers' metacognitive awareness according to the seniority variable. 
Table 5. Results about Teachers' Metacognitive Awareness according to Seniority Variable

\begin{tabular}{|c|c|c|c|c|c|c|c|c|c|}
\hline Sub-Dimensions & Seniority & $\mathrm{n}$ & $\bar{X}$ & SD & $\begin{array}{l}\text { Source of } \\
\text { Variance } \\
\end{array}$ & $\begin{array}{l}\text { Sum of } \\
\text { Squares }\end{array}$ & $\begin{array}{l}\text { Mean } \\
\text { Squares }\end{array}$ & $\mathrm{F}$ & $\mathrm{P}$ \\
\hline \multirow{5}{*}{$\begin{array}{l}\text { Declarative } \\
\text { knowledge }\end{array}$} & $1-5$ years & 75 & 4.10 & .545 & \multirow{2}{*}{$\begin{array}{l}\text { Between } \\
\text { Groups }\end{array}$} & \multirow{2}{*}{2.799} & \multirow{2}{*}{.700} & \multirow{5}{*}{2.537} & \multirow{5}{*}{$.040^{*}$} \\
\hline & $6-10$ years & 122 & 3.91 & .522 & & & & & \\
\hline & $11-15$ years & 104 & 3.89 & .543 & Within & 107883 & 276 & & \\
\hline & $16-20$ years & 51 & 4.02 & .492 & Groups & 107.883 & .210 & & \\
\hline & 21 and high & 44 & 4.04 & .495 & Total & 110.683 & & & \\
\hline \multirow{5}{*}{$\begin{array}{l}\text { Procedural } \\
\text { knowledge }\end{array}$} & $1-5$ years & 75 & 3.85 & .590 & \multirow{2}{*}{$\begin{array}{l}\text { Between } \\
\text { Groups }\end{array}$} & \multirow{2}{*}{2.038} & \multirow{2}{*}{.510} & \multirow{5}{*}{1.510} & \multirow{5}{*}{.199} \\
\hline & 6-10 years & 122 & 3.82 & .565 & & & & & \\
\hline & $11-15$ years & 104 & 3.81 & .596 & Within & 131961 & 337 & & \\
\hline & $16-20$ years & 51 & 3.97 & .580 & Groups & 131.961 & .337 & & \\
\hline & 21 and high & 44 & 4.01 & .574 & Total & 133.999 & & & \\
\hline \multirow{5}{*}{$\begin{array}{l}\text { Conditional } \\
\text { knowledge }\end{array}$} & $1-5$ years & 75 & 4.11 & .572 & \multirow{2}{*}{$\begin{array}{l}\text { Between } \\
\text { Groups }\end{array}$} & \multirow{2}{*}{1.389} & \multirow{2}{*}{.347} & \multirow{5}{*}{1.262} & \multirow{5}{*}{.285} \\
\hline & 6-10 years & 122 & 4.03 & .491 & & & & & \\
\hline & $11-15$ years & 104 & 4.00 & .504 & \multirow{2}{*}{$\begin{array}{l}\text { Within } \\
\text { Groups }\end{array}$} & \multirow{2}{*}{107.618} & \multirow{2}{*}{.275} & & \\
\hline & $16-20$ years & 51 & 4.07 & .517 & & & & & \\
\hline & 21 and high & 44 & 4.19 & .586 & Total & 109.007 & & & \\
\hline & $1-5$ years & 75 & 4.36 & .584 & Between & 3313 & 828 & & \\
\hline & 6-10 years & 122 & 3.91 & .548 & Groups & 3.313 & .828 & & \\
\hline Planning & $11-15$ years & 104 & 3.85 & .583 & Within & & 317 & 2.611 & $.035^{*}$ \\
\hline & $16-20$ years & 51 & 4.07 & .544 & Groups & 124.018 & .317 & & \\
\hline & 21 and high & 44 & 4.09 & .544 & Total & 127.330 & & & \\
\hline & $1-5$ years & 75 & 3.90 & .613 & Between & 1941 & 485 & & \\
\hline & 6-10 years & 122 & 3.93 & .508 & Groups & 1.941 & .485 & & \\
\hline Monitoring & $11-15$ years & 104 & 3.88 & .469 & Within & & & 1.803 & .127 \\
\hline & $16-20$ years & 51 & 4.05 & .509 & Groups & 105.186 & .269 & & \\
\hline & 21 and high & 44 & 4.08 & .493 & Total & 107.126 & & & \\
\hline & $1-5$ years & 75 & 3.94 & .590 & Between & 2550 & 640 & & \\
\hline & 6-10 years & 122 & 3.77 & .590 & Groups & 2.559 & .640 & & \\
\hline Evaluation & $11-15$ years & 104 & 3.82 & .575 & Within & 123867 & & 1.869 & .115 \\
\hline & $16-20$ years & 51 & 3.92 & .618 & Groups & 133.867 & .342 & & \\
\hline & 21 and high & 44 & 3.97 & .547 & Total & 136.427 & & & \\
\hline & $1-5$ years & 75 & 3.85 & .658 & Between & & & & \\
\hline & 6-10 years & 122 & 3.93 & .588 & Groups & .912 & .228 & & \\
\hline Debugging & $11-15$ years & 104 & 3.86 & .559 & Within & 141605 & 362 & .630 & .642 \\
\hline & $16-20$ years & 51 & 3.89 & .624 & Groups & 141.605 & .362 & & \\
\hline & 21 and high & 44 & 4.00 & .613 & Total & 142.517 & & & \\
\hline & $1-5$ years & 75 & 4.00 & .548 & Between & 081 & & & \\
\hline & 6-10 years & 122 & 3.94 & .443 & Groups & .981 & .245 & & \\
\hline $\begin{array}{l}\text { Information } \\
\text { management }\end{array}$ & $11-15$ years & 104 & 3.94 & .475 & Within & 04057 & 243 & 1.010 & .402 \\
\hline & $16-20$ years & 51 & 4.03 & .485 & Groups & 94.957 & .243 & & \\
\hline & 21 and high & 44 & 4.08 & .570 & Total & 95.938 & & & \\
\hline & $1-5$ years & 75 & 3.98 & .510 & Between & 1464 & 366 & & \\
\hline & 6-10 years & 122 & 3.91 & .448 & Groups & 1.464 & .366 & & \\
\hline Total inventory & $11-15$ years & 104 & 3.89 & .455 & Within & 85084 & 220 & 1.665 & .157 \\
\hline & $16-20$ years & 51 & 4.01 & .467 & Groups & 85.984 & .220 & & \\
\hline & 21 and high & 44 & 4.06 & .486 & Total & 87.448 & & & \\
\hline
\end{tabular}

$* \mathrm{p}<.05$

Table 5 indicates that seniority of teachers has no effect on the procedural knowledge $\left[\mathrm{F}_{(4-391)}=1.510, \mathrm{p}>.05\right]$, conditional knowledge $\left[\mathrm{F}_{(4-391)}=1.262, \mathrm{p}>.05\right]$, monitoring $\left[\mathrm{F}_{(4-391)}=1.803, \mathrm{p}>.05\right]$, evaluation $\left[\mathrm{F}_{(4-391)}=1.869, \mathrm{p}>.05\right]$, debugging $\left[\mathrm{F}_{(4-391)}=.630, \mathrm{p}>.05\right]$, information management $\left[\mathrm{F}_{(4-391)}=1.010, \mathrm{p}>.05\right]$ and total inventory $\left[\mathrm{F}_{(4-391)}=1.665\right.$, $\mathrm{p}>.05]$, while it has an effect on the declarative knowledge $\left[\mathrm{F}_{(4-391)}=2.537, * \mathrm{p}<.05\right]$ and the planning $\left[\mathrm{F}_{(4-391)}=2.611\right.$, $* p<.05]$. Scheffe test performed to find the source of the difference revelaed a significant difference between 1-5 years and 11-15 years seniority groups in favor of teachers with $1-5$ years seniority. 


\section{Discussion}

The development of metacognitive skills in early years is important for these skills develop children's awareness about their learning [58]. Therefore, classroom and pre-school teachers need to help children to improve metacognitive awareness from the early childhood. Kramarski \& Kohen [59] state that it can be possible to improve students 'metacognitive awareness only by the development of teachers' metacognitive awareness. For this reason, Wilson \& Bai [60] state that teachers should have pedagogical metacognitive awareness. This is essential because teachers with high metacognitive awareness are the ones who create a positive effect in education [61] and allow students to be more successful in the learning process [62-63]. Therefore, it is important to support teachers in developing their metacognition and understanding of metacognition instruction. It is necessary to educate teachers in terms of metacognitive awareness. In other words, teachers need to be metacognitive first and know how to transfer their own metacognition into instructional practices [64].

In this study, it was found that the levels of the classroom and pre-school teachers' awareness were high. This finding is supported by previous research [65-66-67]. Bars [65], for example, found that the metacognitive awareness levels of pre-school teacher candidates were high. In a different research on metacognitive awareness, Batdi [66] also found that teachers had high levels of metacognitive awareness. In addition, Wilson \& Bai [60] state that the teachers who have a rich understanding of metacognitive knowledge aim to teach metacognitive thinking strategies to be required for their students.

The metacognitive knowledge consists of declarative, procedural and conditional knowledge [68] and refers to what individuals know about themselves as cognitive processors [69]. Declarative knowledge is awareness of self-skills, intellectual capacity and capabilities. Individual can attain this knowledge from presentations, demonstrations and discussions. Especially, procedural knowledge is the knowledge of how to achieve an academic task. Individuals can gain this knowledge by means of exploration, cooperative learning and problem solving. On the other hand, conditional knowledge is knowledge about when and why to utilize abilities. Individuals can gain this knowledge in this way [61]. According to Flavell [22], metacognitive knowledge covers goals, strategies and beliefs and knowledge of academic tasks. Xiaoyan [70] found that teachers had a very low level of awareness about metacognitive knowledge. However, in this study it was found that teachers' awareness of explanatory, procedural and situational information was high.

A great deal of research has shown the effectiveness of teaching metacognitive skills to improve student success [71]. Researchers have found that individuals who use metacognitive skills learn and remember better than those who do not [63]. Griffith, Bauml \& Quebec-Fuentes [72] stated that the high level of metacognitive awareness of teachers about planning, evaluation and review of teaching has a positive effect on the learning process. In this research, it was determined that the metacognitive levels of teachers' planning, monitoring and evaluation sub-dimensions were high. This finding is consistent with the finding of Batdi [66] which showed that the metacognitive awareness levels of the teachers regarding the planning, monitoring and evaluation sub-dimensions were high. Therefore, it can be said that the findings of the research support the results of Batdi [66].

In the current study, it was found that class and pre-school teachers have positive and high level metacognitive awareness of debugging and information management. Similarly, Bars [65] concluded that pre-service teacher candidates have high levels of metacognitive awareness regarding debugging and information management. Therefore this finding supports the finding of the current research.

In this study significant differences were found between the levels of classroom and pre-school teachers' awareness about the declarative, procedural and conditional knowledge, planning, monitoring, evaluation, debugging, information management and total inventory in favor of pre-school teachers. Considering this, it can be said that the level of pre-school teachers' awareness is high than classroom teachers. This difference can be explained that the pre-school teachers have more courses during their undergraduate education. Moreover, the pre-school teachers uses more attractive, interesting, funny and enjoyable activities during their learning process. This makes their profession more enjoyable and this enhance their awareness of meta cognitive skills. In the litarature there are some research that supports this idea. For example the research of SHoaakazemi, et al. [73] suggests a positive and significant relationship between the components of happiness and meta cognitive skills.

In this research, it was also found that there was a significant difference between the teachers' metacognitive awareness levels in favor of female teachers. Saracaloglu $\&$ Cengel [74] point out that there is a relationship between the metacognitive awareness and the gender variable. Moreover, Rozendaal, Minnaert \& Boekaerts [75] reported that females have significantly more surface-level processing strategies than males. Asikcan \& Saban [76] also found that teachers' metacognitive awareness levels differed in favor of female teachers. Besides, Batdi [66] found that there is a significant difference between the metacognitive awareness levels of teachers in terms of gender variable. On account of it can be said this finding is consistent with the findings of results of the research in this literature.

This study also showed that the seniority variable was not effective on the procedural and conditional knowledge, 
monitoring, evaluation, debugging, information management and total inventory, while it was effective on the declarative knowledge and the planning.

\section{Suggestions}

It can be said that classroom and pre-school teachers do not involve spontaneously in metacognitive thinking unless they are clearly encouraged to do so through carefully designed instructional activities [77].

In addition, learning strategies are important in terms of metacognitive awareness. Therefore, it is necessary to develop learning strategies to improve teachers' metacognitive awareness. Teachers must be a "strategic learners" in the learning process. Teachers need to do the several functions to become strategic learners. Teachers need to define the learning situation correctly, choose the learning strategy, monitor the strategies and strive for success. Besides, teachers should give place methods and techniques to improve their metacognitive awareness. Since there is limited research on metacognitive awareness of the teachers, the researhers should make more studies on this issue.

\section{REFERENCES}

[1] Schraw, G., \& Dennison, R. S. Assessing metacognitive awareness. Contemporary Educational Psychology, 19, 460-475, 1994.

[2] Akin, A., Abaci, R., \& Cetin, B. The validity and reliability study of the Turkish version of the metacognitive awareness inventory. Educational Science: Theory \& Practice, 7(2), 655-680, 2007.

[3] Akpunar, B. The analysis of the concepts of cognition and metacognition in terms of the philosophy of mind. Turkish Studies, 6(4), 353-365, 2011.

[4] Garrison, D. R., Anderson, T., \& Archer, W. Critical inquiry in a text-based environment: Computer conferencing in higher education. The Internet and Higher Education, 2, $87-105,2000$.

[5] Bandura, A. Human agency in social cognitive theory. American Psychologist, 44 (9), 1175-1184, 1989.

[6] Demir, M. K., \& Budak, H. The relationship between self-regulating, motivation and metacognitive skills and mathematics success of 4th grade students, Buca Education Journal, 41, 30-41, 2016.

[7] Kilis, S., \& Yildirim, Z. Investigation of community of inquiry framework in regard to self-regulation, metacognition and motivation. Computers \& Education, 126, 53-64, 2018.

[8] Lajoie, S. P. Metacognition, self regulation, and self-regulated learning: A rose by any other name? Educational Psychology Review, 20(4), 469-475, 2008.
[9] Baker, L., \& Brown, A. L. Metacognitive skills and reading. In P. D. Pearson, R. Barr, M. L. Kamil, \& P. Mosenthal (Eds.), Handbook of reading research (pp. 353-394). New York: Longman, 1984.

[10] Pintrich, P. R., Wolters, C. A., \& Baxter, G. P. Assessing metacognition and self-regulated learning. In G. Schraw, L. Murphy \& J. C. Impara (Eds.), Issues in the measurement of metacognition (pp. 43-98). Nebraska, USA: Buros Institute of Mental Measurements, 2000.

[11] Rubenstein, L. D., Callan, G. L., \& Ridgley, L. M. Anchoring the creative process within a self-regulated learning framework: Inspiring assessment methods and future research. Educational Psychology Review, 30(3), 921-945, 2018.

[12] Schraw, G., Crippen, K. J., \& Hartley, K. Promoting self-regulation in science education: Metacognition as part of a broader perspective on learning. Research in Science Education, 36(1-2), 111-139, 2006.

[13] Panadero, E. A review of self-regulated learning: Six model and four directions for reserch. Frontiers in Psychology, 8(422), 2017.

[14] Veenman, M.V.J. The assessment of metacognitive skills: What can be learned from multi-method designs? In C. Artelt ve B. Moschner (Eds.), Lernstrategien und Metakognition: Implikationen fur Forschung und Praxis (pp. 77-99). Munster: Waxmann, 2006.

[15] Akin, A. The relationships between achievement goal orientations and metacognitive awareness, parenting styles and academic achievement [Basari amac oryantasyonlari ile bilis otesi farkindalik, ebeveyn tutumlari ve akademik basari arasindaki iliskiler]. Unpublished master's thesis, Sakarya University, Turkey, 2006.

[16] Bas F., \& Ozturan Sagirli, M. A content analysis of the articles on metacognition in education in Turkey. Education and Science, 42 (192), 1-33, 2017.

[17] Flavell, J. H. Metacognitive aspects of problem solving. In L. B. Resnick (Ed.), The nature of intelligence. Hillsdale, NJ: Erlbaum, 1976.

[18] Lucangeli, D., Galderisi, D., \& Cornoldi, C. Specific and general transfer effects following metamemory training. Learning Disabilities Research \& Practice, 10, 11-21, 1995.

[19] Senemoglu, N. Gelisim ogrenme ve ogretim (16. Baski) [Development learning and teaching (16th edition)]. Ankara: Pegem Academy, 2010.

[20] Stancescu, I., Draghicescu, M. L., \& Petrescu, A.-M. A. Metacognition-A premise for a qualitative academic learning. Revista Romaneasca pentru Educatie Multidimensionala, 10(3), 91-102, 2018.

[21] Subas1, G. Etkili ogrenme: Ogrenme stratejileri [Effective learning: Learning strategies], Milli Egitim Dergisi [National Education Journal], 146, 2000. Retrieved from https://dhgm.meb.gov.tr/yayimlar/dergiler/Milli_Egitim_De rgisi/146/subasi.htm

[22] Flavell, J. H. Metacognition and cognitive monitoring: A new area of cognitive developmental inquiry. American Psychologist, 34, 906-911, 1979.

[23] Nelson, T. O., \& Narens, L. Metamemory: a theoretical 
framework and new findings. In J. Metcalfe \& A. P. Shimamura (Eds.), Metacognition: Knowing about knowing (pp 1-25), Cambridge, MA: MIT Press, 1990.

[24] Wenden, A. Metacognitive knowledge and language learning. Applied Linguistics, 19(4), 515-537, 1998.

[25] Seraphin, K. D., Philippoff, J., Kaupp, L., \& Vallin, L. M. Metacognition as means to increase the effectiveness of inquiry-based science education. Science Education International, 23(4), 366-382, 2012.

[26] Ozsoy, G., \& Ataman, A. The effect of metacognitive strategy training on mathematical problem solving achievement. International Electronic Journal of Elementary Education, 1(2), 68-83, 2009.

[27] Medina, M. S., Castleberry, A. N., \& Persky, A. M. Strategies for improving learner metacognition in health professional education. American Journal of Pharmaceutical Education, 81(4): 78, 2017.

[28] Cetin, B. An investigation of teacher candidates' metacognitive skills according to their year of study at Canakkale. Educational Research and Reviews, 10(1), 10-16, 2015.

[29] Derry, S. J. Strategy and expertise in solving word problems. In C. B. McCormick, G. E. Miller, \& M. Presley (Eds.) Cognitive research strategy: From basic research to educational application (pp 269-302), New York: Springer-Verlag, 1989.

[30] Kyllonen, P. C., \& Woltz, D. J. Role of cognitive factors in the acquisition of cognitive skill. In R. Kanfer, P. C. Ackerman, \& R. Cudeck (Ed.), Abilities, motivation and methodology: The Minnesota Symposium on Learning and Individual Differences ( $p$ p 239-280), Hillsdale, NJ: Lawrence Erlbaum, 1989.

[31] Kiskir, G. Ogretmen adaylarinin bilisotesi farkindalik duzeyleri ile problem cozme becerileri arasindaki iliskinin incelenmesi [Investigation of the relationship between metacognitive awareness levels and problem solving skills of prospective teachers]. Unpublished master's thesis, Ataturk University, Turkey, 2011.

[32] Cakiroglu, A. Ustbilis [Metacognition]. TSA/Yll: 11, S: 2, 2007.

[33] Ozsoy, G. Ilkogretim besinci sinifta ustbilis stratejileri ogretiminin problem cozme basarisina etkisi [The effect of metacognitive instruction on problem solving achievement of fifth grade primary school students]. Unpublished doctoral thesis, Gazi University, Turkey, 2007.

[34] Ozsoy, G. Ustbilis [Metacognition]. Turkish Educational Sciences Journal [Turk Egitim Bilimleri Dergisi], 6(4), 713-740, 2008.

[35] Brown, A. Metacognition executive control, self-regulation, and other more mysterious mechanisms. In F. E. Weinert, \& R. H. Kluwe (Eds.), Metacognition, motivation and understanding (pp 65-116). Hillsdale, NJ: Erlbaum, 1987.

[36] Garrison, D. R., \& Akyol, Z. Toward the development of a metacognition construct for communities of inquiry. Internet and Higher Education, 24, 66-71, 2015.

[37] Rahimi, M., \& Katal, M. Metacognitive strategies awareness and success in learning English as a foreign language: An overview, Procedia - Social and Behavioral Sciences, 31, 73-81, 2012.

[38] Zumbrunn, S., Tadlock, J., \& Roberts, E. D. Encouraging self-regulated learning in the classroom: A review of the literature. Virginia: Metropolitan Educational Research Consortium (MERC), 2011.

[39] Desoete, A. (2008). Multi-method assessment of metacognitive skills in elementary school children: How you test is what you get. Metacognition Learning, 3(3), 189-206, 2008 .

[40] Schraw, G., \& Moshman, D. Metacognitive theories, Educational Psychology Review, 7, 351-371, 1995.

[41] Everson, H. T., \& Tobias, S. The ability to estimate knowledge and performance in college: A metacognitive analysis. Instructional Science, 26(1-2), 65-79, 1998.

[42] Bonds, C. W., Bonds, L. G., \& Peach, W. Metacognition: developing indepence in learning. Clearing House, 66(1), 56-59, 1992

[43] Akyolcu, R. Resim-ís egitimi ana bilim dalı ogrencilerinin ustbilissel farkindaliklari ile okul basarlari arasindaki iliskinin incelenmesi [An investigating of metacognitive awareness and academic achievement among the department of art teaching students]. Unpublished master's thesis, Gazi University, Turkey, 2013.

[44] Duman, B. Ogretim ilke ve yöntemleri (2. Baski) [Teaching principles and methods]. Ankara: Ani Publication, 2011.

[45] Bars, M., \& Oral, B. The relationship among metacognitive awareness, self-efficacy toward the teaching proffession and the problem solving skills of teacher candidates. Eurasian Journal of Educational Research, 72, 107-128, 2017.

[46] Quirk, M. Intuition and metacognition in medical education: Keys to developing expertise. New York: Springer Publishing Company, 2006.

[47] Biggs, J. The role of metacognition in enhancing learning. Australian Journal of Education, 32(2), 127-138, 1998.

[48] Wang, M. C., Haertel, G. D., \& Walberg, H. J. What influences learning? A content analysis of review literature. Journal of Educational Research, 84(1), 30-43, 1990.

[49] Zimmerman, B. J., \& Schunk, D. H. Self-regulated learning and academic achievement. Mahwah, NJ: Erlbaum, 2001.

[50] Hattie, J. A. C. Visible learning. A synthesis of over 800 metal-analyses relating to achievement. London: Routledge, 2009.

[51] Paris, S. G. \& Jacobs, J. E. The benefits of informed instruction for children's reading awareness and comprehension skills. Child Development, 55, 2083-2093, 1984.

[52] Garofalo, J., \& Lester, F. K. (1985). Metacognition, cognitive monitoring and mathematical performance. Journal for Research in Mathematics Education, 16(3), 163-176, 1985.

[53] Eroglu, O. Izleme arastirmalari [Tracking research]. Unpublished master's thesis, Ankara University, Ankara, 2006 . 
[54] Balci, A. Sosyal bilimlerde arastirma, yontem, teknik ve ilkeler (4. Baski) [Research, methods, techniques and principles in social sciences (4th edition)]. Ankara: Pegem Academy, 2004

[55] Buyukozturk, S., Kilic Cakmak, E., Akgun, O. E., Karadeniz, S., \& Demirel, F. (2017). Bilimsel arastirma yontemleri (23. Baski) [Scientific research methods (23rd edition)]. Ankara: Pegem Academy, 2017.

[56] Ellis, J. L. A standard for test reliability in group research. Behavior Research Methods. 45(1), 16-24, 2013.

[57] Pallant, J. SPSS survival manual: A step by step guide to data analysis using the SPSS program. (4th edition), Allen \& Unwin, Berkshire, 2011

[58] Chatzipanteli, A., Grammatikopoulos, V., \& Gregoriadis, A. Development and evaluation of metacognition in early childhood education, Early Child Development and Care, 184(8), 1223-1232, 2014.

[59] Kramarski, B., \& Kohen, Z. Promoting Preservice Teachers' Dual Self-Regulation Roles as Learners and as Teachers: Effects of Generic vs. Specific Prompts. Metacognition and Learning, 12(2), 157-191.

[60] Wilson, N. S., \& Bai, H. The relationships and impact of teachers' metacognitive knowledge and pedagogical understandings of metacognition. Metacognition and Learning, 5(3): 269-288, 2010.

[61] Aktag, I., Semsek, O., \& Tuzcuoglu, S. Determination metacognitive awareness of physical education teachers. Journal of Education and Training Studies, 5(9), 63-69, 2017.

[62] Doğan, A. Metacognition and metacognition based teaching. Middle Eastern \& African Journal of Education Research, 3, 6-20.

[63] Woolfolk, A. Educational psychology. Boston, MA: Allyn and Bacon, 1998.

[64] Ozturk, N. Assessing Metacognition: Theory and Practices. International Journal of Assessment Tools in Education, 4(2), 134-148, 2017.

[65] Bars, M.. Ogretmen adaylarinin ustbilissel farkindaliklari, ogretmenlik meslegine yonelik oz yeterlikleri ve problem cozme becerilerine iliskin algilarinin incelenmesi [A study of perceptions of prospective teachers regarding their metacognitive awareness, self-efficacy fort he teaching profession and problem solving skills]. Unpublished doctoral thesis, Dicle University, Turkey, 2016.

[66] Batdi, V. German teachers' views on in-service field education and meta-cognitive awareness levels in Turkey. $H$. U. Journal Education, 31(4), 796-816, 2016.

[67] Koc, I., \& Kuvac, M. Preservice science teachers' metacognitive awareness levels. European Journal of Educational Studies, 2(3), 43-63, 2016.

[68] Schraw, G. Promoting general metacognitive awareness. In H. J. Hartman (Ed.), Metacognition in learning and instruction: Theory, research and practice (pp. 3-16). Boston: Kluwer, 2001

[69] Chatzipanteli, A, Grammatikopoulos, V., \& Gregoriadis, A. Development and evaluation of metacognition in early childhood education. Early Child Development and Care, 184(8), 1223-1232, 2014.

[70] Xiaoyan, Y. A study on college teachers' and students' metacognition in English reading. Proceedings of the Fourth International Symposium on Education Management and Knowledge Innovation Engineering, Vol. 1 and 2, 96-100, 2011.

[71] Diaz-Greenberg, R., Thousand, J., Cardelle-Elawar, M., \& Ann, N. What teachers need to know about the struggle for self-determination (conscientization) and self-regulation: Adults with disabilities speak about their education experiences. Teaching and Teacher Education, 16(8), 873-887, 2000.

[72] Griffith, R., Bauml, M., \& Quebec-Fuentes, S. Promoting metacognitive decision-making in teacher education. Theory Into Practice, 55(3). 242-249, 2016.

[73] SHoaakazemi, et al., The relationship between happiness, meta cognitive skills (self- regulation, problem- solving) and academic achievement of students in Tehran. Life Science Journal, 10(4), 452-457, 2013.

[74] Saracaloglu, A. S., \& Cengel, M. Predictiveness of gender, age and need for cognition on metacognitive awareness. Inonu University Journal of The Faculty of Education, 14(1), $1-13,2013$.

[75] Rozendaal, J. S., Minnaert, A., \& Boekaerts, M. Motivation and self-regulated learning in secondary vocational education: Information-processing type and gender differences. Learning and Individual Differences, 13(4), 273-289, 2003.

[76] Asikcan, M., \& Saban, A. Prospective teachers' metacognitive awareness levels reading strategies. Cypriot Journal of Education Sciences, 8(1), 23-30, 2018.

[77] Okoza, J., \& Aluede, O. Fostering metacognitive awareness among teachers: Implications for the Nigerian school system. Africa Education Review, 11(4), 614-637, 2014. 